Научная статья

УДК 930.22

DOI: $10.18101 / 2305-459 X-2020-3-63-70$

\title{
УЧЕНИЕ НОМУН-ХАНА ЖАМБАЛ ДОРЖО ГЭГЭНА, АДРЕСОВАННОЕ БУРЯТАМ
}

\section{(C) Тушинов Баир Луданович}

младший научный сотрудник, Институт монголоведения, буддологии и тибетологии СО РАН Россия, 670047, г. Улан-Удэ, ул. Сахьяновой, 6 nurushi@mail.ru

\section{(C) Бухоголова Саяна Батуевна}

научный сотрудник,

Институт монголоведения, буддологии и тибетологии СО РАН

Россия, 670047, г. Улан-Удэ, ул. Сахьяновой, 6

sayana050379@yandex.ru

Аннотация. В статье рассматривается исторический источник на монгольской письменности «Достигший наивысшей мудрости», автором которого является монгольский лама, иерарх буддийской сангхи Жамбал Доржо гэгэн (1886-1938), имевший титул «Номун-хан». Анализ текста позволил установить непрерывающиеся связи монгольской сангхи с бурятским народом, вошедшим в состав Российского государства, в частности с родом хариад. Известно, что установление границ между Монголией и Россией не стало препятствием для представителей бурятских племен отправляться в паломничество к Богдо-гэгэну и святым местам Монголии для поклонения, совершения подношений и получения учений, несмотря на жесткие пресечения со стороны обоих государств. Одним из таких учений, полученных бурятами, являются наставления Жамбал Доржо гэгэна, имевшего в то время несомненный авторитет среди верующих. Они преподаны легким для понимания способом, с приведением множеств аллегорий, послуживших благоприятным условием для восприятия учения. Очевидно, послание Жамбал Доржо было его прямой устной речью и, по сути, является фиксацией его лекции. На это указывают некоторые повторения в тексте, присущие устному воспроизведению материала. Безусловно, это сочинение служит ценным источником для получения представления о живой традиции передачи учения от учителя к ученику и о формах распространения буддийского учения среди бурятских племен в XIX-XX вв.

Ключевые слова: Жамбал Доржо гэгэн; Номун-хан; Ламрим; Шажан; буряты; монгольско-российские отношения; бурятский род хариад; монгольские рукописи; этапы пути.

Благодарность. Работа выполнена в рамках государственного задания (проект «Памятники письменности народов Внутренней Азии: исследование, перевод и презентация», АААА-А19-119111300043-4).

\section{Для цитирования}

Тушинов Б. Л., Бухоголова С. Б. Учение Номун-хана Жамбал Доржо гэгэна, адресованное бурятам // Вестник Бурятского государственного университета. Язык. Литература. Культура. 2020. Вып. 3. С. 63-70. 


\section{Введение}

Исследуемое нами Учение крупного иерарха монгольской буддийской Сангхи Хамба Жамбал Доржо Номун-хана под названием: «Достигший высшей мудрости» (Orui-yin degedü manglai boluysan orušibai, «Оройн дээдэ манлай болоһон орошобай», «Оройн дээдэ манлай болоһон орошобай» $)^{2}$ в настоящее время хранится в монгольском фонде Центра восточных рукописей и ксилографов ИМБТ СО РАН. Рукопись написана на классической монгольской письменности на 17 страницах бумаги производства фабрики И. И. Маршева размером $11 * 35$ см [4, с. 106]. Сохранность и целостность бумаги отличная, не подверглась внешнему механическому воздействию. Предположительно, рукопись относится к началу $\mathrm{XX}$ века и принадлежит руке неизвестного бурята, что удостоверяют некоторые бурятизмы в тексте. Историческую и культурную ценность рукописи подчеркивает и тот факт, что на сегодняшний день это единственное зафиксированное сочинение Жамбал Доржо-гэгэна в каталоге ЦВРК.

Известна другая рукопись Жамбал Доржо под названием «Поучения Жам-

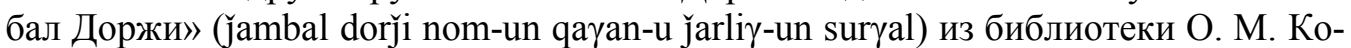
валевского, хранящаяся под шифром С 47 (№ 4628) в составе «Коллекции КДА» (Казанской духовной академии) монгольского фонда Отдела рукописей и документов Института восточных рукописей РАН. В 1927 году эту коллекцию доставили в ИВР РАН после закрытия Казанской духовной академии [13, с. 1289].

\section{Общее содержание рукописи}

Рукопись содержит поэтапно изложенные буддийские наставления. В начале после строк с традиционным благопожеланием кратко представлена личность автора послания Жамбал Доржо гэгэна: «Это Учение "Врата легкого обретения этапов пути к Пробуждению" преподал Жамбал Доржо гэгэн — потомок Богдо Чингиса, ставший наивысшим главой северного [ара] халхаязычного народа от простолюдинов до ханов, Предводитель Желтого Учения, являющийся воплощением речи Джецуна Дамбы Таранатхи гэгэна. Эти наставления были распространены для принесения блага всем живым существам» [3, c. 1v].

Здесь прослеживается второе название текста: «Врата легкого нахождения этапов Пути к Пробуждению». Этапы пути к Пробуждению ${ }^{3}$ - это классический способ последовательного объяснения Учения, соответствующий уровням развития учеников. Ламрим излагает этапы пути для низшей, средней и высшей личностей. Личности низшего уровня заботятся об обретении хорошего перерождения после смерти в сферах людей и богов с целью дальнейшего совершенствования. Личности среднего уровня прилагают усилия для освобождения от круговорота сансары. Личности высшего уровня стремятся к состоянию будды чтобы наилучшим образом принести благо всем живым существам. Личности первого

\footnotetext{
${ }^{1}$ букв. — «Ставший наивысшим главой».

2 При работе с текстом и осуществлении перевода были использованы академические словари: [БАМРС, 2002-2003, 1901 с.; Ковалевский, 1844-1849, 2690 с.]

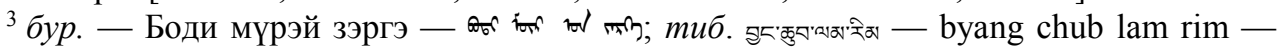
Жанчуб ламрим.
} 
уровня стараются закрыть врата рождений в низших мирах: мирах ада, голодных духов, животных и обрести лучшее перерождение. Эта классификация трех личностей нисколько не принижает личность отдельного человека, в лучшем случае относится к этапам развития одной личности в течение одной жизни. В изучаемом нами тексте поучения Жамбал Доржо гэгэна, направленные на улучшение будущей жизни ориентированы на достижение рождения в Сукхавати 1 .

Второе название школы Гелуг звучит как «Шара Шажан» — «Желтая вера». Слово Шажан в монгольском языке является заимствованным из санскрита словом Шасана ${ }^{2}$. В изучаемой нами рукописи обнаружены некоторые примеры так называемых бурятизмов - слов на монгольской письменности, написанных без общепринятых правил орфографии, с использованием речевых оборотов бурят-

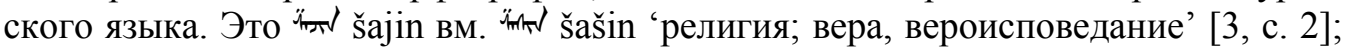

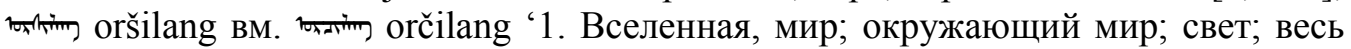
мир; 2. религ. круговорот перевоплощений души' [3, с. 4r]; үюю юбюr idikü idigen вм. tтюि भont idekü idegen 'еда, пища, кушанье; стол, снедь' [3, с. 2v] и др., указывающие на то, что текст был записан носителем бурятского языка.

Упоминание в начале текста, что Жамбал Доржо является потомком Богдо Чингиса, говорит о происхождении Жамбал Доржо гэгэна из золотой ветви чингисидов. Определение в названии рукописи «Оройн дээдэ манлай болоһон орошиба» следует отнести к личности самого автора Жамбал Доржо: «Ставший наивысшим главой северного [ара] халхаязычного народа от простолюдинов до ханов» $[3$, с. $1 \mathrm{v}]$.

Интересно утверждение, что Жамбал Доржо воплощает речь Джебцзуна Дамбы Таранатхи гэгэна. В буддизме считается, что высокореализованный лама способен явить одновременно множество своих нирманакай ${ }^{3}$ и также проявлять отдельно нирманакаи своего тела, речи и ума. Утверждение в рукописи о том, что Жамбал Доржо гэгэн - воплощение речи Джебцзуна Дамбы Таранатхи, следует понимать так, что Богдо гэгэн и Жамбал Доржо рассматривались в монгольском духовенстве нераздельно как воплощения одной личности Таранатхи, т. к. Богдо гэгэн является признанным перерождением Таранатхи [3, c. 1v].

В отношении к Жамбал Доржо в рукописи употребляются самые высокие титулы, свидетельствующие о его авторитете среди верующих: Гэгэн - Светлейший, Номун-хан - Царь Дхармы, Эрдэни хутухта - Драгоценный святой, Халха Джебцзун Дамба Жалсаб - регент Халха Джебцзун Дамбы. Титул Жал-

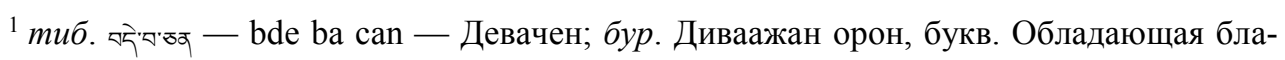
женством. Чистая земля Будды Амитабхи, в которой нет ни малейшего страдания. Согласно буддийским представлениям, индивид может родиться в этой земле, накопив большой запас положительной кармы, очистив проступки и совершая молитвы о рождении в ней.

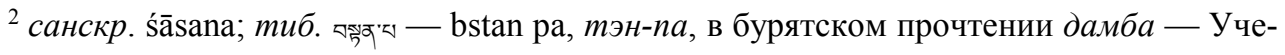
ние, доктрина, религия.

${ }^{3}$ Нирманакая — санскр. nirmāṇakāya; тиб. 종ㅊㅐㅐㄱ — sprul sku — тулку; бур. хубилгаан rootim - воплощение, проявленное тело.
} 
саб ${ }^{1}$ наделяет Жамбал Доржо гэгэна полномочием выражать интересы Халха Джебцзун Дамбы Богдо-хана VIII - главы буддистов Монголии. Как признанный перерожденец Жамбал Доржо владел личной печатью на управление шабинарами - учениками, полученной от маньчжурского императора. Исследователи указывают неодинаковое число халхасских хутухт, 12, 13 или 19, обладавших такой печатью на управление в начале XIX в. [8, с. 57].

В речи, произнесенной Жамбал Доржо: «Затем вы, северный народ, подданные Почтенного [Абай] Белого Царя, поддерживаемого тэнгри, живущие на соседних землях, говорящие на языке халха, мои жиндаги ${ }^{2}$ из больших и малых улусов; поскольку вы до сих пор продолжаете верно слушать Учение Будды, оно обладает долей распространяться начиная со страны Ваджры (Индии) вплоть до внешнего океана до завершения этой кальпы» [3, с. 1v], автором подчеркивается подданство бурят Белому Царю 3 и выражается уважение царю при помощи слова Абай ююr (Батюшка, Почтенный) [5, с. 40]. Тем самым Жамбал Доржо гэгэн фактически признает факт вхождения бурятских племен в состав Российского государства. Поскольку на тот момент в монгольском обществе продолжала сохраняться неоднозначная позиция по поводу присоединения бурят к России, обращение гэгэна в позитивном русле позволяет выявить мирное отношение монгольской Сангхи указанного периода, что, безусловно, повлияло на ход построения гармоничных межгосударственных отношений [1, с. 380].

Далее гэгэн обращается к представителям бурятского рода хариад 4 : «Поэтому вы, мои люди, живущие в приграничье с Халхой, ставшие моими жиндагами, относящиеся к роду хариад, слушайте, что я вам скажу о двух: встретить и не встретить Учение Будды; и таких двух как: войти и не войти в Учение Будды» [3, c. 2 r].

\section{Бурятский род хариад}

Род хариад как род бурятского происхождения в настоящее время широко не известен, хотя о нем встречаются сведения в различных источниках. Монгольский ученый Цонгоол Б. Нацагдорж предполагает, что название хариад было экзоэтнонимом бурят, которых именовали их южные соседи халха-монголы. Для них этнонимы хариад и буриад были двумя разными названиями одних и тех же монголоязычных этносов северного берега озера Байкал [17, с. 3].

Нацагдорж приходит к выводу, что хариады, упоминаемые в халхасских хрониках «Sir-a tuүuji» и «Asaraүči neretü-yin teüke», скореe всего, были не кто иными, как бурятами Прибайкалья, Саянского и Тункинского региона, входившими в ойратский союз с XIV по XVI в. [там же, с. 13].

\footnotetext{
${ }^{1}$ тиб. Б्रुळ‘ - rgyal tshab - представитель, регент.

2 Жиндаг - тиб. 췋ऽㄲ — sbyin bdag - хозяин даяния. Благотворитель, поддерживающий Сангху, Учителей подношением материальных даров, ученик.

${ }^{3}$ Белый Царь Николай II (Николай Александрович Романов, 1868-1918).

${ }^{4}$ Харийад, харяад омог тол крайнем западе Бурятии, впоследствии эмигрировавшая в Монголию [7, с. 148].
} 
Исследователь Аюудайн Очир придерживается такой же версии: «Хариад еще в древности представлял один из бурятских родов и входил в состав ойратов. По сведениям старожилов этого рода, проживающих в Монголии, родоначальником рода хариад был бурят по имени Батбаянжаргал, которого (а также и его сыновей Гүнсэндара и Онхотөмөр) вскормил беркут у озера Байкал. Из этих сведений можно сделать вывод, что представители рода хариад пришли от байкальских бурят к ойратам и халхам, а их тотемом был беркут. "Хариад" в переводе означает "инородный, чужестранный", этноним в своей основе восходит к монгольскому слову "харь" (чужой)» [8, с. 201].

По мнению Б. З. Нанзатова происхождение рода «хариад» берет начало от ашибагатов, одной из крупных этнических групп бурят, которые населяли Прибайкалье на крайнем западе Бурятии. Впоследствии в XVII в. род хариад мигрировал в Монголию, где смешался с монгольскими племенами и вошел в халхамонгольский этнос. «Очевидно, что потомки бурят-мигрантов XVII-XVIII вв. ассимилировались с окружающим населением, но благодаря традиции ретрансляции родословной потомки бурятских эмигрантов в северо-западной и западной Монголии, по нашему предположению, сохранили бурятское самосознание. Таким образом, несмотря на ассимиляцию ранних бурят-эмигрантов в Монголии, есть основания говорить о непрерывности традиции воспроизводства содержания исторической памяти в этнических группах бурятского происхождения $[7$, c. 148].

Несмотря на смешение с монгольскими племенами, в современное время многие хариады Монголии продолжают идентифицировать себя с этнонимом хариад: «Сейчас в Монголии проживает семь тысяч представителей этого племени, которое считается частью халха-монгольского этноса. Но так было не всегда, хариаты помнят о том, что они потомки бурят, бежавших со своей родины в XVII в.» $[10$, с. 2]. Частично вернувшиеся в конце XVIII в. в Бурятию хариады вошли в состав селенгинских бурят, в частности в род сартулов (род хариан) [11, c. 234].

Из источника следует, что хариады продолжали оставаться на территории России на рубеже XIX-XX вв. под своим этнонимом хариад, затем, по всей видимости, смешавшись с крупными бурятскими родами, потеряли собственную этническую идентичность.

\section{Учение Жамбал Доржо гэгэна}

В своем обращении Жамбал Доржо гэгэн проповедует преимущества благого образа жизни, отказ от десяти неблагих деяний и обретение счастливого рождения в чистой земле Сукхавати. Интерес представляет наставление гэгэна, относящееся к устной традиции (санскр. упадеша, бур. убдис) о том, что причиной рождения в Сукхавати становится непосредственное пребывание рядом с Учителем и слушание Учения. Жамбал Доржо гэгэн говорит, что в это время затрагивается тонкое сознание слушателя и в сочетании с благопожелательной молитвой Учителя создается сильная благая причина рождения в Сукхавати: «Реализующей причиной того [рождения] станет движение тонкого сознания при жизни во 
время пребывания на Учении и вознесения из уст Учителя молитвенного благопожелания» $[3$, с. $3 \mathrm{v}]$.

Далее гэгэн отмечает распространенные сомнения людей и приводит в пример имевшую место в то время ритуальную форму погребения с лошадью: «Обманываясь такими мыслями, люди думают, что после смерти будущая жизнь будет схожа с настоящей, и когда кто-то умирает, убивают находящегося рядом невинного здорового коня в сбруе и седле, чтобы после смерти он служил хозяину. Рядом с усопшим кладут необходимые в быту вещи, инструменты, одежду и т. д.» $[3$, с. 5 r] .

Обычай умерщвления коня на могиле и погребения вместе с покойником практиковался в древности многими народами. У бурят этот обряд назывался хойлого морин угэхэ, и данные о существовании такого обычая у аларских и агинских бурят встречаются в работах М. Н. Хангалова и П. П. Баторова [12, c. 329]. Жамбал Доржо гэгэн приводит данный пример в качестве заблуждения, которое было вызвано страстной привязанностью при жизни.

С целью порождения страха у слушателей перед низшими мирами сансары гэгэн подробно останавливается на красочном описании страданий в восемнадцати адах: восьми горячих, восьми холодных и дополнительных; страданиях голодных духов и животных. Говоря о животных, Жамбал Доржо гэгэн затрагивает тему происхождения всех видов живых существ на земле. Следует заметить, что этот взгляд соответствует научному взгляду о выходе животных на сушу из воды:

«Живые существа мира животных не в силах избежать страданий, омраченные невежеством, поедают живьем друг друга, подвергаются многим страданиям, убийствам, гонениям и порабощениям людьми и богами. Большинство животных обитает в большом океане. Малая часть распространившихся из него животных, обитающих на этой Джамбудвипе, начиная с червяков, рожденных в сырости, и до домашних животных, появившихся на свет в тепле, используется людьми» [3, с. $14 \mathrm{r}]$.

Эти описания полностью соответствуют описаниям страданий низших миров в классической буддийской литературе. Согласно книге «Жанчуб Ламрим» Ламы Цонкапы, страх перед возможными будущими страданиями после смерти становится действенным фактором принятия буддийского Прибежища и воздержания от неблагих деяний.

«Ом мани бадмэ хум! О, бедные невежественные живые существа! Если, памятуя о тех страданиях, очищать свои проступки и совершать благие деяния, вы не испытаете подобные страдания» [3, с. 13r].

В заключительной части текста гэгэн напутствует, что, становясь последователями буддизма, совершая благие и отказываясь от неблагих деяний, люди тем самым становятся на путь, ведущий к Сукхавати - Обители блаженства. Образ Сукхавати как счастливой, безмятежной земли Будды Амитабхи, где нет страданий, является наиболее популярным среди образов других чистых земель в буддизме Махаяны. Гэгэн обращается с просьбой к слушателям, хуваракам и мирянам распространить его Учение, делясь им с другими людьми. Текст завершается молитвой к Ламе Цонкапе, Таранатхе и Далай-ламе с благопожеланием, строками о пользе слушания Учения и изложением десяти неблагих и десяти благих деяний. 


\section{Выводы}

На основе данного исторического источника становится возможным сделать вывод, что, несмотря на установление российских границ на территории Восточной Сибири, и становление внутренней бурятской сангхи, обретшей к тому времени большую степень независимости от влияния тибетского и монгольского духовенства, бурятские племена и иерархи монгольской сангхи продолжали поддерживать духовные связи до революции 1917 г.

Обращаясь к ключевым моментам источника, мы наблюдаем главное послание Жамбал Доржо к слушателям о буддийском принципе ненасилия - ахимсе, непричинении вреда всему живому и также самому себе, чтобы после смерти получить хорошее перерождение. Отметим, что Жамбал Доржо гэгэн преподает наставления мирянам в легкой доступной форме, простым языком, без использования специфической буддийской терминологии.

\section{Лuтература}

1. Лама Жамбал Доржо гэгэн и его трактат «Достигший высшей мудрости» / И. Г. Актамов [и др.] // Научный диалог. 2020. № 6. С. 371-385. DOI: 10.24224/2227-12952020-6-371-385.

2. Большой академический монгольско-русский словарь: в 4 т. / Ё. Баярсайхан [и др.] Институт языка и литературы Академии наук Монголии; Институт языкознания PAH. M.: Academia, 2002-2003. 1901 c.

3. Жамбал Доржо гэгэн. Достигший высшей мудрости (Orui-yin degedь manglai bolursan oruљibai, «Оройн дээдэ манлай болоһон орошобай») // Монгольский фонд Центра восточных рукописей и ксилографов Института монголоведения, буддологии, тибетологии Сибирского отделения Российской академии наук. M-V-100, 17 л.

4. Клепиков С. А. Филиграни и штемпели на бумаге русского и иностранного производства XVII-XX вв. М.: Изд-во Всесоюзной Книжной палаты, 1959. 106 с.

5. Ковалевский О. М. Монгольско-русско-французский словарь. Казань: Казанский государственный университет, 1844-1849. Т. І-ІІІ. 2690 с.

6. Нанзатов Б. 3. Племенной состав бурят в XIX веке // Народы и культуры Сибири. Взаимодействие как фактор формирования и модернизации. 2003. С. 15-27.

7. Нанзатов Б. З. Этнический состав и расселение народов Монгольского Алтая и Прихубсугулья в начале XX века // Известия Иркутского государственного университета. Серия «Геоархеология. Этнология. Антропология». 2013. № 2(3). С. 138-151.

8. Очир А. Монгольские этнонимы: вопросы происхождения и этнического состава монгольских народов. Элиста: КИГИ РАН, 2016. 286 с.

9. Скрынникова Т. Д. Ламаистская церковь и государство. Внешняя Монголия. XVI — начало XX века. Новосибирск: Наука. Сиб. отд-ние, 1988. 104 с.

10. Цыбикдоржиев Д. Исторический фон самой знаменитой дуэли в степи [Электронный ресурс]. URL: https://yehe.asia/articles/themes/istoriya/380-historical _background _famous_duel_in_the_great_steppe/ (дата обращения: 07.10.2020).

11. Цыдендамбаев Ц. Б. Бурятские исторические хроники и родословные. Историколингвистическое исследование. Улан-Удэ: Бурятское книжное издательство, 1972. 664 с.

12. Цыденова Д. Ц. Похоронно-погребальный обряд агинских бурят // Проблемы истории, филологии, культуры. Магнитогорск, 2007. № 18. С. 325-346.

13. Яхонтова Н. С. Материалы О. М. Ковалевского в Отделе рукописей и документов Института восточных рукописей РАН // Учен. зап. Казан. ун-та. Сер. Гуманит. науки. 2018. Т. 160, кн. 6. С. 1289-1306. 
14. Byamba-yin Asaraүui neretь-(yin) teьke. Галиглаж үгийн хэлхээг үйлдэн, эх бичгийн судалгаа хийсэн Ц. Шагдарсүрэн. Улаанбаатар, 2002.

15. Dan-Aajab, T. BNMAU-yn Ugsaatny zbi. Khalkhyn ugsaatny zbi [The ethnography of the MPR. The ethnography of Khalkh]. Ulaanbaatar: Ulsyn khevleliin gazar, 1987. V. I. $163 \mathrm{x}$.

16. Лхагважав Л. Хамба номун хан Жамбалдоржийн цадиг түүх. Улаанбаатар, 2006.

17. Natsagdorj Tsongol B. On the people of Khariad // Etudes Mongoles et Siberiennes, Centrasiatiques et Tibetaines. Centre d`etudes mongoles et Siberiennes. 2015. V. 46. P. 1-19.

\title{
NOMUN-KHAN JAMBAL DORJO GEGEN'S TEACHING GIVEN TO THE BURYAT PEOPLE
}

\author{
Bair L. Tushinov \\ Junior Researcher, \\ Institute for Mongolian, Buddhist and Tibetan Studies SB RAS \\ 6 Sakhyanovoy St., Ulan-Ude 670047, Russia \\ nurushi@mail.ru
}

Sayana B. Bukhogolova

Researcher, Institute for Mongolian, Buddhist and Tibetan Studies SB RAS 6 Sakhyanovoy St., Ulan-Ude 670047, Russia sayana050379@yandex.ru

Abstract. This article examines a historical document written in Mongolian script: "The One Who Attained the Highest Wisdom", authored by a Mongolian Lama, a Buddhist Sangha hierarch Jambal Dorjo gegen, known also by his title of "Nomun Khan". The analysis of this text made it possible to confirm the links between the Mongolian Sangha and the Buryat people that became a part of the Russian polity, the Khariad clan in particular. It is known that even with the establishment of borders between Mongolia and Russia, the Buryat tribes continued to go on pilgrimages to Bogdo-gegen and various sacred sites in Mongolia for worship. They continued offering tirbute and receiving Teachings from the Sangha despite both governments' efforts to put a stop to this. One such Teaching given to the Buryats were the sermons given by Jambal Dorjo gegen, who undoubtedly enjoyed a high position of authority amongst the faithful. They were provided in a simple, easy-to-understand format that often used allegory to get their point across, which made internalising the Teaching that much easier. It is obvious that the record of Jambal Dorjo's messages is a direct transcript of his oral lessons and lectures. This is evidenced by the numerous repetitions indicative of spoken language.

Without a doubt, this historical document serves as a valuable source of knowledge about the living tradition of transferring the Teachings from Teacher to student and various ways the Buddhist teachings have spread amongst the Buryat tribes in XIX-XX centuries. Keywords: Jambal Dorjo gegen; Nomun Khan; Lamrim; Shajan; Buryats; MongolianRussian relations; Buryat's clan Khariad; Mongolian manuscripts; stages of the path.

Статья поступила в редакичию 26.10.2020; одобрена после рецензирования 13.11.2020; принята к публикации 01.12.2020. 